\title{
AC 2011-418: INTERNATIONAL CO-OP EXPERIENCE AT THE BASE OF THE ECONOMIC PYRAMID FOR ENGINEERING STUDENTS
}

\section{John Farris, Grand Valley State University}

John Farris is currently an associate Professor in the Padnos College of Engineering and Computing at Grand Valley State University (GVSU). He earned his Bachelors and Masters degrees at Lehigh University and his Doctorate at the University of Rhode Island. He has 12 years of college engineering teaching experience as well as 3 years of industrial design experience. His teaching interests lie in the product design, first year design, design for manufacture and assembly and manufacturing processes. Dr. Farris is also involved in the development and delivery of a new graduate biomedical engineering masters degree with a focus on the medical device development

\section{Paul Merritt Lane, Grand Valley State University}

Dr. Lane is a Professor of Innovation in the Brooks College of Interdisciplinary Studies and teaches in the Seidman College of Business. Over the last 11 years Lane has worked with his engineering coauthor in new product, entrepreneurship, innovation, and particularly innovation at the base of the economic pyramid. 


\title{
International Co-op Experience at the Base of the Economic Pyramid for Engineering Students
}

\begin{abstract}
An increasing number of employers, students and engineering schools are recognizing the value of meaningful international and intercultural experiences. However, students in prerequisite driven curriculums like engineering find it hard to fit time to go abroad into their schedules without delaying graduation. The problem compounded for students in institutions that require periods of cooperative education. This paper describes a program designed to address these concerns while challenging students cultural frameworks and engineering talent.

The program provides participating students with an in-depth cultural immersion experience in Nicaragua, the second poorest country in the Western Hemisphere. During the three-week program students learn limited Spanish, live with local host families, take a business and culture class, work in a local manufacturing company and work with local students to design and build a product to meet a need identified by local community members. The program is based in Estelí, Nicaragua where the faculty sponsors have extensive experience and contacts. The faculty co-sponsors have run an innovation and entrepreneurship program in Estelí for the past five years. The program is specifically designed to appeal to engineering students and fit into the perquisite driven engineering curriculum.
\end{abstract}

The objectives of the program are listed below.

1. Provide an opportunity for students majoring in engineering to participate in a study abroad program.

2. Provide an opportunity for students majoring in engineering live, learn and work in a culture at the base of the economic pyramid.

3. Provide an opportunity for students majoring in engineering to design products for people living at the base of the economic pyramid.

During the first week of the program, students will spend their mornings in Culture, Business and Language class. A local language school is providing a customized mix of essential Spanish language training, visits to local businesses and culturally relevant community excursions. In the evenings students will have a chance to process their experience through discussions with faculty and journaling. During the afternoons of the first week the students will work with local students to repair products brought in by community members. This activity will help the students understand the resources and technology available to the community. During the afternoons of the second week students will work in local manufacturing companies to learn how companies operate and solve problems in a different culture at the base of the economic pyramid. In the third week, students from the US and Nicaragua will work together to design and prototype solution to a problem identified by local community members. The aim of the combined team will be to design a solution that can be made in Nicaragua and sold at a price that average Nicaraguans can afford. The weekends will be reserved for visiting a rural community and sightseeing. Upon returning the students will take up regular Co-op assignments to complete the requirements for the co-op cycle. The program has been approved by the university and the first offering is planned for May, 2011. 


\section{Rational for the Program}

The International Co-op program has been designed to address the issues that have prevented engineering students from participating in study abroad programs. These issues can be classified into three broad categories; the prerequisite driven engineering curriculum, the small size of the engineering school and the mandatory co-op requirement. The prerequisite driven curriculum means that engineering courses must be taken in a specific order. Therefore if a student takes time off to participate in a study abroad program it is very likely that their graduation date will be delayed at least a semester. Compounding this problem is the fact that many junior and sophomore required engineering courses are only offered once a year. The root cause of this situation is the small number of engineering students. The engineering school graduates only 70 students per year spread over four emphases; Computer Engineering, Electrical Engineering, Mechanical Engineering and Product Design and Manufacturing. A student who misses a required course that is only offered once a year, will have to wait an entire year before the class is offered again. In addition all other courses that have the missed class as a prerequisite must also be delayed.

| It is not uncommon for one missed class to delay a student's graduation for a full academic year.

One unintended consequence of the three cooperative education periods mandated by the engineering school is the fact that they effectively dissuade students from participating in study abroad programs. The co-op requirement was instituted when the engineering program was created. The local industry that financially supported the creation of the school pushed hard for the co-op requirement to ensure that graduates had the skills and knowledge required to help companies compete in the global economy and grow. Students are reluctant to miss a co-op experience because many co-ops lead to an offer of permanent employment and students can make more than $\$ 600$ per week to defray the cost of their education. The co-op mandate is implemented by having periods of co-op alternated with semesters in class. Students do their first co-op after successful completion of their sophomore year. Then the alternating periods of co-op and classes begin. After three co-op periods the students finish their education with two consecutive semesters of study. This schedule is shown in figure 1 .

\begin{tabular}{|l|l|l|}
\hline \multicolumn{1}{|c|}{ Fall Semester } & \multicolumn{1}{|c|}{ Winter Semester } & \multicolumn{1}{c|}{ Spring/Summer Semester } \\
\hline \multicolumn{2}{|c|}{ Freshman Year } & No Required Activities \\
\hline \multicolumn{2}{|c|}{ Sophomore Year } & Co-op 1 \\
\hline Junior Classes & Co-op 2 & Junior Classes \\
\hline Co-op 3 & Senior Classes & Senior Classes \\
\hline
\end{tabular}

Table 1. Distribution of Co-op periods and study periods in the engineering curriculum.

The enhanced co-op program that is proposed provides a vehicle to make study abroad for engineering students feasible and attractive within the very structured format of the engineering programs. It is not a replacement for a co-op period. When the students return to from Nicaragua, they must complete the requirement for co-op by working at another company

\section{Description of the Program}

The proposed program provides participating students with an in-depth cultural immersion experience. During the three-week program students will learn limited Spanish, live with local host families, take a business and culture class, work in a local manufacturing company and work with local students to design and build a product to meet a need identified by community members. The program is based in Estelí, Nicaragua where the faculty sponsors have extensive experience and contacts. The faculty co-sponsors have run an innovation and entrepreneurship program in Estelí for the past five years. The program is specifically designed to appeal to engineering students and fit into the perquisite driven engineering curriculum.

\section{Objectives}

1. Provide an opportunity for students majoring in engineering to participate in a study abroad program.

2. Provide an opportunity for students majoring in engineering Live, learn and work in a culture at the base of the economic pyramid.

3. Provide an opportunity for students majoring in engineering to design products for people living at the base of the economic pyramid. 


\section{Pre-departure Activities and Orientations}

To prepare students to work safely in Nicaragua, each student will complete a machine shop qualification before departure. Every student in the engineering school is required to take this short safety and machine operation course before they are allowed to work in The University's shops. The Engineering Laboratories supervisor will conduct the instruction which consists of 3 sessions. The first 75 minute session covers shop safety, the second 75 minute covers the operation of manual mills and lathes and the final 60 minute session covers welding. After the sessions, students must produce a part to be certified. Typical students complete the part in 4 hours of work in the shop.

The faulty sponsors will use on-line resources and two face to face meetings to prepare students for the trip. To facilitate previous non-credit trips to Nicaragua, the faculty sponsors have used a Blackboard course site to post information for students. This on-line source of information accommodates students' busy and varying schedules. The recommended packing list, required forms, required immunizations, information describing Nicaragua and a "frequently asked questions" sections have been all been posted for past trips. In addition two face to face meetings will be held. The first meeting will be held in Early April and cover the history of the university's involvement in Nicaragua, the mission and vision of the program, the itinerary of the trip and the answers to any questions. The second face to face will happen one week before departure. Details of the departure and the meeting in Managua, last minute questions, contact information while in Nicaragua and expectations will be covered at the meeting.

Students in the business and culture course will complete approximately $1 / 3$ of the course work hours before departing for Nicaragua. In one face to face meeting, a short history of modern Nicaragua will be presented to give the students a framework for understanding what they will see and learn in Nicaragua. A great deal of current culture will be covered in the two pre-trip meetings that have to do with trip organization. Students will have three major assignments to complete before they leave. These assignments will be turned in online and discussed on line. In the first assignment, students will introduce themselves and present why they have chosen this course and this program. The second assignment will be focused on the culture of Nicaragua or issues at the base of the economic pyramid. The third assignment will be a background piece on the demographics, and economics of Nicaragua. This assignment is designed to enable students to become familiar with what Nicaragua is like today. The sponsors have learned that students do much better in course work if they know more before they arrive.

\section{Itinerary}

The itinerary is shown in Figure 1. The group will meet in Managua on Saturday and Stay at Backpackers Inn the first night. On Sunday the group will transfer to Estelí, meet their host families and settle into their rooms. In the afternoon, the group will tour the downtown district of Estelí and find CENAC, UPONIC and FAREM. In the evening the group will gather for a short meeting to discuss the schedule for the first week.

During the first week of the program, students will spend their mornings in Culture, Business and Language class. A three credit course must contain 45 contact hours of instruction. Field trips, if done with a lecturer and closely linked to the academic program through pre-visit lectures, readings, post-visit discussions, etc. may count towards the 45 hours at 50\%. For example, 2 hours of a field trip (excluding travel time) is equivalent to one hour of formal instruction. In general, a three credit course with 45 contact hours cannot be completed in a two-week trip. Table 3 shows how the proposed program meets the criteria. The required hours for the co-op class will be met by the students working at regular co-op placements when they return from Nicaragua. 


\begin{tabular}{|c|c|c|c|}
\hline & Morning & Afternoon & Evening \\
\hline Week 1 & $\begin{array}{l}\text { Culture Class } \\
\text { Culture Business and } \\
\text { language }\end{array}$ & $\begin{array}{l}\text { Repair Products for } \\
\text { Residents }\end{array}$ & $\begin{array}{l}\text { Reflection, processing, } \\
\text { faculty led discussions, } \\
\text { debriefings and journaling }\end{array}$ \\
\hline Weekend & \multicolumn{3}{|c|}{$\begin{array}{l}\text { Visit Revolutionary Monument, Entrepreneurial Cookie Factory, Solar Center, Typical } \\
\text { Mountain Community, and Somoto Canyon Faculty Lead Discussions and Debrief. }\end{array}$} \\
\hline Week 2 & $\begin{array}{l}\text { Spanish Class } \\
\text { Culture Business and } \\
\text { language }\end{array}$ & $\begin{array}{l}\text { Work in Local } \\
\text { Manufacturing Companies }\end{array}$ & $\begin{array}{l}\text { Reflection, processing, } \\
\text { faculty led discussions, } \\
\text { debriefings and journaling }\end{array}$ \\
\hline Weekend & \multicolumn{3}{|c|}{$\begin{array}{l}\text { Visit Miraflor Biological Reserve, Conversations with co-op members, understanding the } \\
\text { coffee business, ecotourism as it is developing in Nicaragua. Faculty led Discussion and } \\
\text { Debriefing. }\end{array}$} \\
\hline Week 3 & $\begin{array}{l}\text { Culture Class } \\
\text { Culture Business and } \\
\text { Language }\end{array}$ & $\begin{array}{l}\text { Design and Prototype } \\
\text { solution to local problem }\end{array}$ & $\begin{array}{l}\text { Reflection, processing, } \\
\text { faculty led discussions, } \\
\text { debriefings and journaling }\end{array}$ \\
\hline Weekend & \multicolumn{3}{|c|}{ Transfer to Managua, visit Huembes market, overnight Backpackers Inn and fly home. } \\
\hline
\end{tabular}

Table 2. The weekly itinerary.

\begin{tabular}{|c|c|c|}
\hline & Enhanced EGR Co-op & Culture Class \\
\hline $\begin{array}{l}\text { Classroom Lectures, } \\
\text { Discussions, Debriefings }\end{array}$ & N/A & $\begin{array}{l}15 \text { hours pre departure } \\
\text { (Lecture, Discussions } \\
\text { partially on line) } \\
15 \text { hours of Discussions } \\
\text { and Debriefings }\end{array}$ \\
\hline $\begin{array}{l}\text { Field Trips (count at a } 1 / 2 \\
\text { rate.) }\end{array}$ & N/A & $\begin{array}{l}16 \text { hours (in Estelí and } \\
\text { on weekend trips, 32/2) }\end{array}$ \\
\hline $\begin{array}{l}\text { Other (count at a rate of } \\
1 / 3 \text { ) }\end{array}$ & N/A & $\begin{array}{l}11.3 \text { hours General } \\
\text { Culture } 34 / 3^{*}\end{array}$ \\
\hline Total & N/A & 57.3 hours \\
\hline
\end{tabular}

Table 3. Distribution of contact hours for the courses offered.

\section{How the Program Meets the Goals of the University's Study Abroad Objectives}

The proposed program provides participating students with an in-depth cultural immersion experience. During the program students will learn Spanish, live with local host families, take a business and culture class, work in a local manufacturing company and work with local students to design and build a product to meet a need identified by

| community members. CENAC is providing a customized mix of business_and organization visits, community excursions with the students and essential Spanish language training. CENAC has worked with the faculty sponsors for five years in their Estelí Innovation program and has proven they can provide customized business, culture and language training tailored to the needs of program participants.

It is anticipated that student will make about three organizational visits per week and work individually or in small groups going into the community as well as working on language. Participants will learn phrases and vocabulary that is relevant to their work. Staying with local families gives the students a unique immersion opportunity to learn the language and culture of Nicaragua by observing and interacting with their host families. Students will be able to learn more about the culture when they spend the second week of the program working in local companies. Discovering how companies operate and solve problems in a different culture is expected to be one of the most | significant learning opportunities for participants. 
The culture course will provide a more academic view of the culture. In the third week the students will work with local students to design and prototype a product that meets a community need and can be manufactured in the community. This is a significant technical and cultural challenge. The technical challenge arises from the limited technology available and the need to make any product affordable to a population with the second lowest per capita income in the Western Hemisphere. (CIA world Fact book) Fortunately the faculty sponsors have been working with the FAREM and UPONIC on similar problems for over five years.

The proposed program has been planned with student safety in mind. Estelí, the programs base city, is a fast growing and progressive city of about 119,000 people that is the commercial and cultural center for the northern part of Nicaragua. Estelí is located on the Pan-American Highway, 150 kilometers north of Managua. Estelí is one of the safest small cities in Latin America. The faculty sponsors have lead student groups in Estelí for over five years without any problems. In addition, CENAC has years of experience hosting North Americans in Estelí. They have dealt with medical emergencies in the past and have excellent contacts with the local clinics and hospitals. In addition all participating companies will be inspected by the faculty sponsors to ensure a safe working environment. To prepare students to work safely in Nicaragua, each student will complete a machine shop qualification before departure. This orientation, conducted in the machine shop by the shop supervisor consists of 3 sessions. The first 75 minute session covers shop safety, the second 75 minute covers the operation of manual mills and lathes and the final 60 minute session covers welding. After the sessions, students must produce a part to be certified. Typical students complete the part in 4 hours of work in the shop.

\section{Expected Costs}

Some of the students' expected costs are shown in the table 4 below:

\begin{tabular}{|l|r|}
\hline STUDENT EXPENSES (PER STUDENT) & Budgeted \\
\hline Transfer from/to the airport & $\$ 20$ \\
\hline Lodging in Managua & $\$ 30$ \\
\hline Food in Managua & $\$ 35$ \\
\hline Transportation in Managua & $\$ 25$ \\
\hline Lodging and food in Estelí & $\$ 450$ \\
\hline Travel to from Estelí \$10+\$10 & $\$ 20$ \\
\hline Additional food in Estelí & $\$ 10$ \\
\hline Trip to Samoto ( travel \$10+ food $\$ 40+$ lodging $\$ 30)$ & $\$ 80$ \\
\hline Trip to Miraflor ( travel \$10+ food $\$ 50+$ lodging $\$ 40)$ & $\$ 100$ \\
\hline Lab rental $\$ 20$ per the first week and $\$ 15$ the following 2 weeks & $\$ 50$ \\
\hline Work supervisor and translator & $\$ 40$ \\
\hline Program Development Funding & $\$ 75$ \\
\hline Contingency Funds (\$300/no. of students) & $\$ 50$ \\
\hline Processing Fee & $\$ 5$ \\
\hline Sub total & 990 \\
\hline
\end{tabular}

Table 4. Expected costs of the program.

The costing information may be useful to other faculty interested in planning a similar program.

\section{Conclusion}

An increasing number of employers, students and engineering schools are recognizing the value of meaningful international and intercultural experiences. Students in prerequisite driven curriculums like engineering find it hard to fit time to go abroad into their schedules without delaying graduation. The program provides participating students with an in-depth cultural immersion experience in Nicaragua, the second poorest country in the Western Hemisphere. The administration has guaranteed the program will run for three years in order to build participation. Therefore the next step is to create an assessment plan that measures how well the program meets the objectives. 


\title{
APPENDIX 1 SYLLABI FOR BUS 301 AND EGR 290
}

\author{
B U S 301 \\ Business, Entrepreneurship and Culture in Nicaragua
}

Course Objectives:

Syllabus

This course is a study of how entrepreneurship and business are accomplished in Nicaragua and how national culture influences business and entrepreneurship. The course examines the basic concepts of culture, the culture of Nicaragua and the impact of Nicaragua's culture on the business and entrepreneurial environment. The course explores issues in how entrepreneurship and small business development reflect the history, economics, politics, government and the educational systems of Nicaragua.

\section{Content Objectives}

Lectures by Host Country Specialists and/or Faculty on Entrepreneurship and small business development Lectures by Host Country Specialists and/or Faculty in aspects of history and culture of Nicaragua

Company and organizational visits with presentations by company executives/staff focusing on the issues in starting and maintaining a small business

Skill Objectives (in addition to content)

Gain Awareness of a Foreign Culture as it Applies to Business and Entrepreneurship

Acquire Skills Required to Adapt to

Improve Information Gathering Skills

Improve Writing Skills

Improve critical thinking about culture and business

Textbooks:

Beyond Cultures by Hall.

When the Ak-47s Fall Silent: Revolutionaries, Guerrillas, and the Dangers of Peace by Timothy C. Brown

Assessments:

Student's grade will be based upon a number of assignments. At the discretion of the instructor, assessments may include, but are not limited to:
Exams
Journal
Research Project(s)
Attendance and Participation

Final Grade:

Total points will be divided by total possible points and the final grade will be assigned according to the following schedule.

$\begin{array}{llll}\text { A } & 93.0-100 \% & \text { C }+ & 77.0-79.9 \% \\ \text { A- } & 90.0-92.9 \% & \text { C } & 73.0-76.9 \% \\ \text { B+ } & 87.0-89.9 \% & \text { C- } & 70.0-72.9 \% \\ \text { B } & 83.0-86.9 \% & \text { D } & 60.0-69.9 \% \\ \text { B- } & 80.0-82.9 \% & \text { F } & \text { Less than } 60 \%\end{array}$

Contact Hours:

Suggested use of the forty-two Contact Hours:

\begin{tabular}{|c|l|}
\hline$\%$ of course* & \multicolumn{1}{|c|}{ Topic } \\
\hline $50 \%$ & Lectures/ Guest/Host Country Specialists and/or Faculty \\
\hline $20 \%$ & Culture Tours \\
\hline $20 \%$ & Site/Company Visits \\
\hline $10 \%$ & Contingency \\
\hline
\end{tabular}


*Approximate and may vary depending on instructor. 


\section{EGR 290 - ENGINEERING CO-OP 1 \\ School of Engineering}

\section{9-2010 Catalog Description:}

EGR 290 Engineering Co-op 1. The first full-time four-month cooperative engineering work experience usually in a local industrial/manufacturing firm. Reading, writing assignments required. At least one evening meeting required. Prerequisites: Acceptance into B.S.E. degree program, employability through standard interview process, EGR 289. Must have permission of the co-op director. Three credits. Offered spring/summer semester.

Required or Elective: $\quad$ Required for all students

Textbook/Required Material: James G. Skakoon, W.J. King, The Unwritten Laws of Engineering: Revised and Updated, A.S.M.E. Press, The Giver, Lois Lowry

\section{Learning Objectives:}

1. The student will demonstrate the ability to function as an engineer in an industrial environment. (ABET: a, d, e, f, g, h, j, k, l)

2. The student will demonstrate an understanding of professional ethics. (ABET: $f, g$ )

\section{Topics Covered:}

Because every co-op site and every co-op period is different it is not possible to list topics in the same way that is possible for lecture/lab classes. Students will gain the topical coverage required for them to perform in the industry into which they have been placed. Many students do gain significant design experience (ABET $\mathrm{c}$ and $\mathrm{d}$ ) however it will be different for each student and since it will be delivered by a co-op employer, difficult for the faculty to oversee. The opportunity to engage in the full complexity of an engineering work environment is the "valueadded" part that can only be provided by the work environment. Common to all students: the journal with at least weekly entries and other written assignments as well as the ethics case study.

Coordinator: $\quad$ Shirley T. Fleischmann, Professor

\section{Class Schedule:}

This is a full-time work experience required in the B.S.E. degree program. 